\title{
Islam dan Demokrasi : Kebebasan dan Hak Asasi dalam Pandangan Racid Ghannoushi
}

\author{
Hasbiyallah \\ Jurusan Sejarah Peradaban Islam IAIN Syekh Nurjati Cirebon \\ hasbiromli@gmail.com
}

\begin{abstract}
ABSTRAK
Tunisia merupakan sebuah negara yang berhasil meraih kemerdekaan dari Prancis pada tahun 1954. Kultur budaya yang ada di Tunisia memang sangat kental dengan budaya Islam Arab, dan bahkan mampu memberi pengaruh signifikan bagi politik di Tunisia. Pengaruh tersebut selanjutnya mendapat respon beragam dari para tokoh pemimpin negara itu, dimulai dari masa kepemimpinan Bourguiba yang dianggap otoriter oleh rakyat Tunisia yang kemudian dikudeta oleh Ben Ali tahun 1989. Oleh kerena itu, banyak kalangan menyayangkan serta berupaya untuk mengantisipasi hilangknya nilai-nilai luhur tersebut dengan menggaungkan demokrasi sebagai wadah kebebasan dan terjaminnya hak asasi manusia, salah satu tokoh tersebut adalah Rachid Ghannoushi yang senantiasa memperjuangkan tumbuhnnya nilai-nilai kebebasan dan hak asasi manusia bagi segenap rakyat Tunisia.

Jenis penelitian yang penulis gunakan adalah penelitian pustaka (library research) yang bersifat deskriptif-analitik-kualitatif. Ruang lingkup penelitian dibatasi pada demokrasi pandangan Ghannoushi sebagai objek penelitian serta kebebasan dan hak asasi manusia sebagai unit analisis. Sedangkan metode pengumpulan data dilakukan dengan penelahaan bahan-bahan pustaka baik yang terdiri dari bahanbahan yang bersifat primer maupun sekunder, dan metode analisis data dalam penelitian ini menggunakan model analisis dari Miles dan Huberman, serta tahaptahap penelitian dalam penelitian ini menggunakan metode Bogdan, yaitu tahap pra lapangan, tahab kegiatan, dan tahap analisis data.

Hasil penelitian menunjukkan bahwa pandangan Ghannoushi terhadap demokrasi begitu kuat. Ia berpendapat bahwa demokrasi selalu mengutamakan hak asasi, kebebasan dan keadilan tidak bertentangan dengan syariat Islam, bahkan demokrasi seiring dengan tuntutan Maqasid Syari'ah. Ghannoushi melihat demokrasi itu sebagai sesuatu yang progresif dan dinamis sebagai sistem yang berpangkal kepada kuasa rakyat (rakyat adalah sumber kekuasaan) untuk menjamin hak-hak dan kebebasan.
\end{abstract}

Kata Kunci: Rachid Ghannoushi, Demokrasi, Kebebasan, Hak Asasi Manusia. 


\section{PENDAHULUAN}

Dalam kajian pemikiran politik Islam, persoalan Islam, kebebasan, dan hak asasi manusia sebenarnya merupakan bagian dari pembahasan agama dan politik. Ketiga poin itu tentu berkaitan dengan demokrasi yang hingga saat ini masih selalu hangat diperbincangkan. Nilai-nilai tersebut juga memunculkan persoalan dan menjadi perdebatan panjang berbagai kalangan yang hingga kini belum menemukan titik temu.

Ada tiga alasan penting mengapa pembahasan tentang kebebasan dan hak asasi manusia dalam Islam selalu menarik? Pertama, sumber atau rujukan bahasan ini sangat banyak dan kaya. Ini merupakan hasil akumulasi pengalaman Dunia Muslim dalam membangun kebudayaan dan peradaban selama sekitar lima belas abad. Pengalaman historis ini menjadi modal penting, dan sekaligus menumbuhkan banyak sumber bagi penulisan tentang Islam dan demokrasi, khususnya di Dunia Muslim. Kedua, kompleksitas permasalahan Islam, kebebasan dan hak asasi manusia yang dibahas. Ini mendorong para pengkaji atau peneliti kepada pembahasan dengan menggunakan satu atau beberapa pintu pendekatan yang sangat spesifik. Sebab, bila menggunakan pendekatan yang menyeluruh, maka dituntut tidak hanya kemampuan menyeluruh pula, tapi juga kesadaran untuk tidak terjebak kepada reduksionisme dan kecenderungan untuk meyederhanakan masalah sebenarnya sangat kompleks dan rumit. Ketiga, adanya pandangan ideologis berbagai kelompok masyarakat muslim. Akibatnya, pembahasan tentang Islam, 
kebebasan dan hak asasi manusia akan terus berkepanjangan, dan tak akan pernah berhenti. ${ }^{1}$

Kebebasan dan hak asasi manusia merupakan cerminan dari prinsip demokrasi dan menjadi isu global yang terus berkembang hingga saat ini, dan setidaknya dalam wacana pemikiran Islam terdapat tiga grand pemikiran; menolak, menerima dan mengakomodasi. Namun, wacana yang demikian di dalam realitasempirik menunjukkan suatu yang berbeda. Bagi mereka yang dianggap menerapkan ajaran Islam dalam kehidupan keseharian cenderung tidak merespon isu-isu tersebut dengan bijaksana. Sementara, di sisi lain terdapat suatu fenomena sebaliknya. Demokrasi sering kali dikaitkan dengan ideologi Barat yang tidak boleh diterima dan diamalkan sepihak. ${ }^{2}$ Ada segelintir golongan yang menolak demokrasi secara total dan ada juga yang menganggapnya sebagai perbuatan menyekutukan Tuhan.

Terlepas dari pergolakan pemikiran para tokoh tentang pandangan terhadap prinsip kebebasan dan hak asasi manusia sebagai bagian dari prinsip demokrasi, muncul sosok tokoh yang justru mendambakan demokrasi menjadi sebuah prinsip kenegaraan demi terjaminnya kesejahteraan rakyat. ia adalah seorang tokoh yang dilahirkan di Tunisia bernama Rachid Ghannoushi (selanjutnya penulis mengunakan istilah Ghannoushi).

Tunisia adalah sebuah negara merdeka yang terletak di ujung utara benua Afrika. Tipikal lanskap geografisnya sangat dipengaruhi oleh kultur Mediterranea dan Gurun Sahara. Luas wilayahnya adalah 63.200 mil persegi atau sekitar 164.000 km2 dengan perbatasan laut Mediterrania di sebelah Timur dan Utara, Aljazair di

\footnotetext{
${ }^{1}$ Nurcholis Madjid, Islam dan Politik: Suatu Tinjauan Atas Prinsip-prinsip Hukum dan keadilan, Jurnal Pemikiran Islam Paramadina, Vol 1 No 1, (Jakarta : Paramadina, 1998), hlm. 48.

${ }^{2}$ Bayat, Asef, Islam and Democracy: What is the Real Question? Amsterdam: Amsterdam University Press, 2010.
} 
Barat dan Barat Daya serta Libya di Selatan dan Tenggara. Terletak di tengahtengah Selat Gibraltar dan Terusan Suez serta hanya berjarak 86 mil dari pulau Sicilia Italia, Tunisia menempati posisi Geopolitik yang sangat strategis sebagai penghubung antara Eropa dan Afrika, serta antara bagian Timur dan bagian Barat dunia Arab. Bersama Maroko dan Aljazair, Tunisia membentuk sebuah zona regional yang disebut dengan Arab Maghreb.

Ibukota Tunisia adalah Tunis yang tumbuh dari sebuah kota kuno Carthage yang berjarak $10 \mathrm{~km}$ dari laut Mediterranea. Kota Carthage dengan pelabuhannya merupakan pusat kebudayaan bersejarah terkemuka di wilayah itu sejak dari abad 9 SM sampai dengan abad 8 M. Hampir semua warga Tunisia adalah Muslim (97\%), sedangkan sisanya adalah warga minoritas Yahudi dan komunitas Eropa. Bahasa nasional adalah bahasa Arab dengan dialek yang nyaris seragam. Sedangkan, bahasa Perancis berkedudukan sebagai bahasa resmi kedua. Tetapi, sangat minim warga yang nyaman dengan bahasa Prancis. Kefasihan berbahasa Perancis menjadi simbol status sosial dan menjadi pintu bagi warga Tunisia untuk melakukan kontak internasional. Sistem pendidikan yang diterapkan di Tunisia adalah sistem bilingualism, dengan beberapa pengecualian pada beberapa sekolah elit yang mulai menggunakan bahasa Inggris.

Ghannoushi adalah pemimpin Partai An-Nahdah (kebangkitan), yang didirikan pada 1988. Ide pemikiran Ghannoushi berkembang melalui proses pendidikan dan pengalaman dalam gerakan Islam. Selain itu pemikiran Ghannoushi juga dipengaruhi oleh pemikir-pemikir hebat dunia Islam yang lain, seperti Ibnu Khaldun, Ibnu Rushd, Jamal al Din Al Afghani, Muhammad Abduh, Hassan al Banna, Ibnu Ashur, Malik Bennabi dan al Maududi termasuk Yusuf al Qardhawi.

Ghannoushi berpandangan bahwa demokrasi yang mengutamakan hak asasi, kebebasan dan keadilan sama sekali tidak bertentangan dengan syariat Islam, bahkan ia sangat seiring dengan tuntutan Maqasid Syari'ah. Ghannoushi melihat 
demokrasi itu sebagai sesuatu yang progresif dan dinamis yaitu sistem yang berpusatkan kepada kuasa rakyat (rakyat adalah sumber kekuasaan) untuk menjamin hak-hak dan kebebasan.

\section{HASIL DAN PEMBAHASAN}

\section{A. Latar Belakang Kehidupan}

Rachid Ghannoushi Khriji dilahirkan di sebuah desa kecil bernama al-Hama wilayah Propinsi Qabis Tunisia Selatan pada 22 Juni tahun 1941. ${ }^{3}$ Ayahnya merupakan seorang petani dan memikul tanggungjawab cukup besar sebagai kepala keluarga, yaitu empat orang istri dan 10 orang anak, termasuk diantaranya Ghannoushi. Ayahnya merupakan orang yang saleh dan satu-satunya penduduk desa yang mampu menghafal seluruh ayat al-Qur'an. Ghannoushi adalah anak dari istri keempatnya dan selalu dididik tentang pentingnya pendidikan yang kemudian memberikan dampak signifikan bagi kehidupan Ghannoushi sebagai seorang profesor, hakim, dan aktivis Islam. ${ }^{4}$

Pola bimbingan dan arahan ibunya sangat berpengaruh terhadap pola pikir Ghannoushi, khususnya terhadap masalah perempuan. Ia selalu dibekali arahan untuk menjadi sosok dengan kepribadian yang kuat dan keyakinan bahwa

\footnotetext{
${ }^{3}$ Majdi Abdul Mu'thi, Rachid Gannoushi: al-Nahdhah al-Islamiyah fi Tunis, (Mesir: al-Dar al-Dzahabiyah, 2012), hlm. 5.

${ }^{4}$ Jhon L- Esposito and Jhon O. Voll, Tokoh Kunci Gerakan Islam Kontemporer, terj. Sugeng Harianto dkk, cet. ke-1(Jakarta: PT. Raja Grafindo Persada, 2002), hlm. 101. Selain itu, Syaikh Majdi menyebutkan dalam sebuah hiwar bersama Gannoushi sebagai berikut:

ومع أن والدي تزوج أكثر من إمرأة إلا أن الإنسجام بين الزوجتين كان إنان إنسجاما كبيرا. حتى إننى كنت أدعو

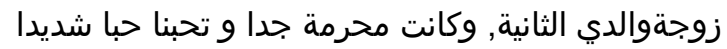
Meskipun ayah saya menikah lebih dari wanita, tetapi keselarasan antara dua istri adalah harmoni ) yang besar. Jadi saya mengundang Anda Zojhoalda kedua, dan dilarang cinta yang sangat besar dan mengasihi kita.( Lihat dalam Majdi Abdul Mu'thi, Rachid Gannoushi: al-Nahdhah al-Islamiyah fi Tunis, (Mesir: al-Dar al-Dzahabiyah, 2012), hlm. 5.
} 
pendidikan akan membuka pintu dunia bagi anak-anaknya. ${ }^{5}$ Keluarga Ghannoushi merupakan satu-satunya keluarga di masyarakat pedesaan yang lambat laun berani meninggalkan dunia pertanian dan perdagangan menjadi bagian dari komunitas profesional terpelajar modern.

Ghannoushi mulai aktif sekolah sejak usia sepuluh tahun dan fokus mempelajari bahasa Arab dan Perancis di sebuah sekolah dasar di daerah al-Hama. Meskipun ia tergolong lambat memasuki dunia pendidikan, namun Ghannoushi sudah mampu menulis dan membaca pada awal dia masuk sekolah. Dalam perjalanannya, Ghannoushi sempat berhenti sekolah karena permintaan ayahnya yang terkendala masalah ekonomi, selain itu ayahnya keberatan jika Ghannoushi belajar bahasa Prancis yang notabene adalah bahasa penjajah negeri tercintanya. ${ }^{6}$

Ghannoushi kembali melanjutkan studinya pada tahun 1956 setelah saudara laki-lakinya lulus dan dapat menggantikannya membantu orang tua dirumah. Ia melanjutkan sekolah di Zaetouna (madrasah) di kota Gabes, tempatnya memperoleh ijazah teologi sebelum akhirnya sekolah itu ditutup oleh pemerintah. Sistem pendidikan yang diterapkan di Zaetouna merupakan pengembangan

\footnotetext{
${ }^{5}$ Ibid., hlm. 102-103.

${ }^{6}$ Tunisia merupakan negara jajahan Prancis. Kemerdekaan negara ini dicapai pada tahun 1956 dan selama lebih dari tiga puluh tahun dipimpin oleh seorang presiden bernama Habib Bourguiba. Bourguiba merupakan sosok berpengaruh yang masa kepemimpinannya menjadikan Tunisia sebagai negara sekuler total. la membawa Tunisia pada jalur modernisasi yang sangat proBaratdan sekuler serta bersekutu dengan Prancis dan Amerika Serikat. Hal ini menjadikan Tunisia sebagai negara yang memilki corak tradisi ala Prancis, bukan tradisi Arab atau Islam yang justru terhimpit di negara yang berpenduduk mayoritas muslim ini. Bahasa resmi Tunisia adalah bahasa Prancis, baik untuk pendidikan, budaya, dan juga masyarakat elit. Pada tahun 1957, Tunisia mengesahkan Undang-Undang Status Pribadi yang jauh melampaui negara muslim lainnya dalam hal larangan poligami bagi penduduknya. Bahkan, Bourguiba berani melarang peempuanperempuan Tunisia menggunakan jilbab dan menjadikan budaya Barat sebagai pendekatan simbolis total bagi agama dan modernisasi, ditambah lagi dengan larangan berpuasa bagi pekerja. Puasa dianggapnya sebagai ritual yang dapat merusak dan mempengaruhi produktifitas dan perkembangan ekonomi Tunisia. Lebih dari itu, Bourguiba juga berani menutup Zaetouna, subuah pusat pembelajaran Islam terkenal di Afrika Utara. Menurut Bourguiba, Islam mewakili masalalu, dan Barat merupakan satu-satunya harapan untuk kemajuan masa depan yang modern. Lebih jelasnya lihat dalam ibid., hlm. 100.
} 
jaringan-jaringan sekolah agama berdasarkan pada kurikulum Islam secara formal. Seperti halnya al-Azhar Mesir, sekolah Zaetouna mengkombinasikan kurikulum Islam tradisional dengan mata kuliah modern. ${ }^{7}$ Ghannoushi sendiri berupaya gigih mempelajari al-Qur'an dan hukum Islam serta teologi dan materi kelimuan modern lainnya dengan berbahasa Arab. Pendekatan dan kajian Islam yang diterapkan di sekolah itu berorientasi klasik dan sangat tradisional, oleh karenanya Ghannoushi mengkritik sistem tersebut sebagai suatu yang tidak berkembang. ${ }^{8}$ Pertama, sistem pendidikan di Zaetouna seakan didesain membosankan, siswa seolah-olah masuk dalam museum. Penekanan yang dilakukan lebih pada praktek-praktek resmi masa lalu daripada relevansi Islam dengan kondisi kontemporer. Kedua, orientasi budaya dan pendidikan ala Prancis yang berkembang di Zaetouna mambuat seleksi masuk sangat kental dengan sistem Prancis, kecuali sistem yang diterapkan di Fakultas Teologi. Dengan demikian, prospek lulusannya cenderung sulit diterima sebagai guru atau pendidik agama.

Kemudian pada tahun 1962, Ghannoushi melanjutkan pendidikannya di Fakultas Teologi Universitas Zaetouna. Akan tetapi, ia tidak dapat menamatkan pendidikannya di universitas tersebut, karena ia justru manantang gurunya dengan pertanyaan seputar filsafat Barat yang berakibat pada pengunduran dirinya di akhir masa kuliahnya. Bahkan, Ghannoushi berpendapat bahwa Zaetouna bukanlah ladang dari munculnya pergerakan Islam, khususnya di Tunisia dan pergerakan Islam lainnya, seperti Ikhwan al-Muslimin dan Jama'ah al-Islamiyah di Pakistan, walaupun saat itu Zaetouna diduga banyak orang sebagai sekolah paling berpengaruh di dataran Arab dan Afrika. ${ }^{9}$ Setelah itu ia mencoba berkarir sebagai

\footnotetext{
${ }^{7}$ Ibid., hlm. 103.

${ }^{8}$ Ibid.

${ }^{9}$ Ghannoushi memberikan argumen sebagai berikut:

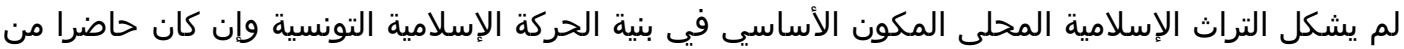

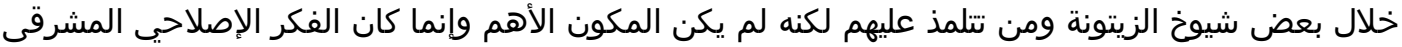
كما إتتهى إليه بالخصوص عند الإحوان المسلمين والجماعة تلإسلامية في لئه باكستان.
} 
seorang guru sekolah dasar selama dua tahun dan memiliki keinginan untuk untuk menjadi wartawan.

Pada tahun 1964, Ghannoushi hijrah ke Mesir dan mendaftarkan diri kuliah di Universitas al-Azhar. Tetapi, upayanya untuk melanjutkan jenjang perkuliahan terganggu ketika Presiden Bourguiba khawatir akan pengaruh paham sosialis Arab Nasser, dan pada akhirnya menarik semua pelajar Tunisia. Hal itu tidak menyiutkan nyali Ghannoushi untuk tetap belajar, kemudian masih dalam tahun yang sama 1964, ia memilih Universitas Damaskus di Syria sebagai labuhan keinginannya tersebut. Di Syria, Ghannoushi memperoleh gelar sarjana muda bidang filsafat pada tahun 1968 dan terus ia kembangkan, salah satunya bergabung dengan Partai Sosialis Nasional Syria (Syrian Nasionalist Sosialist Party), sebuah partai pan-Syria yang cukup kental dengan pengaruh Nasser. ${ }^{10}$

(Warisan Islam tidak merupakan komponen utama dalam struktur lokal dari Tunisia da gerakan Islam Dan yang hadir selama beberapa tua-tua Zaytuna dan dididik mereka tapi itu bukan komponen yang paling penting Tapi hal itu dianggap reformasi Mashraky Global Trading juga berakhir khususnya ketika Alahawwan Tlasalamah Komunitas Muslim di Pakistan )

Lebih lengkap lihat dalam Rachid Gannoushi, al-Harakah al-Islamiyah fi Tunis, (Tunis: Dar alMujtahid, 2011), hlm. 96

${ }^{10}$ Majdi Abdul Mu'thi, hlm 15 


\section{KEBEBASAN DAN HAK ASASI MANUSIA}

\section{Pandangan Rachid Ghannoushi}

Dalam konteks ini, dijelaskan pandangan umum Ghannoushi tentang kebebasan (al-hurrîyyah) dan hak asasi manusia (al-huquq al-insan) di dalam Islam sesuai dengan prinsip-prinsip HAM universal yang sudah dikenal oleh masyarakat dunia.

\section{a) Kebebasan}

\section{a. Kebebasan Berkeyakinan}

Kebebasan berkeyakinan menurut Ghannoushi adalah kebebasan seorang individu dalam memilih keyakinannya tanpa paksaan apapun. Seorang pakar ilmu ushul, Syaikh al-Thahir ibn Asyur, berpandangan bahwa salah satu dasar syariat (ushîl al-syarî'ah) adalah kebebasan berkeyakinan dengan melarang berbagai sarana pemaksaan. Selain itu, syariat juga mengharuskan kepada setiap penganut agama agar menjaga keyakinannya dengan menegakkan kebenaran, serta menghindari fitnah (kekacauan) dengan tidak mencela keyakinan orang lain yang berbeda. Salah satu tujuan jihad di dalam syariat adalah menjaga kebebasan berkeyakinan serta pluralitas agama tanpa adanya paksaan. ${ }^{11}$

Sebagian besar pakar tafsir dan fikih berpendapat bahwa ayat yang berbunyi, "Tidak ada paksaan dalam agama,"12 merupakan salah satu kaidah Islam terbesar dan merupakan salah satu rukun toleransi di dalamnya. Islam tidak membolehkan

\footnotetext{
${ }^{11}$ Rachid Ghannoushi, Al-Hurriyah al- 'Ammah fi al-Daulah al-Islamiyah, hlm 44

12 al-Baqarah: 256
} 
siapapun memaksa seseorang untuk masuk ke dalam agama tertentu, dan tidak membolehkan siapapun memaksa seseorang untuk keluar dari agama tertentu. Untuk menjamin tidak adanya paksaan, Islam memerintahkan umat Muslim untuk kukuh menjaga keyakinan mereka dari rongrongan orang lain serta melakukan dakwah dengan hikmah (kebijaksanaan), maw'iżah hasanah (nasihat yang baik), serta mujâdalah bi al-latîy hiya a hsan (berdebat dengan cara terbaik).

Dengan demikian, tidak heran bila banyak pemikir Muslim yang berpendapat bahwa kebebasan berkeyakinan merupakan kebebasan paling dahulu, merupakan dasar bagi kebebasan-kebebasan yang lain, dan merupakan hak asasi pertama manusia.

Terkait prinsip kebebasan berkeyakinan di dalam masyarakat Muslim menurut Ghannoushi ada beberapa hal yang perlu dibahas di sini, yaitu persamaan sebagai kaidah interaksi di dalam masyarakat muslim. ${ }^{13}$ Di dalam al-Qur'an terdapat ayat yang memerintahkan umat Muslim untuk memerangi orang-orang kafir, dan ada juga ayat lain yang berisi larangan paksaan dalam agama. Namun, bila dilihat konteksnya, ayat berisi perintah untuk memerangi orang-orang kafir lebih bersifat khusus, misalnya kaum musyrikin Quraisy yang selalu mengganggu ketenangan umat Muslim dalam beribadah. Yang diperangi adalah prilaku buruk mereka yang gemar membuat keonaran, bukan keyakinan mereka. Karena Islam secara tegas melarang paksaan dalam hal beragama dan berkeyakinan. ${ }^{14}$

Selain persamaan sebagai kaidah interaksi di dalam masyarakat muslim menurut Ghannoushi, yang penting pula dibahas adalah kebebasan menegakkan syi'ar-syi'ar agama. Islam memberikan tanggung jawab kepada para penganut agama/keyakian untuk membangun rumah-rumah ibadah dan syiar-syiar agamanya sesuai dengan keyakinan masing-masing guna menjaga pendapat publik dan

\footnotetext{
${ }^{13}$ Rachid Ghannoushi, Al-Hurriyah al- 'Ammah fi al-Daulah al-Islamiyah, hlm 46

${ }^{14}$ Ibid
} 
perasaan masyarakat secara umum berdasarkan prinsip kebebasan beragama dan tanpa paksaan. Hal ini, paling tidak, bisa kita lihat dari wasiat-wasiat tegas para khalifah kepada para komandan pasukan perang supaya membiarkan dan tidak mengganggu orang-orang yang sedang khusyu' beribadah di rumah-rumah ibadah. Para khalifah membiarkan umat Muslim hidup berdampingan dengan orang-orang non-Muslim secara rukun dan damai. ${ }^{15}$

\section{b) Kebebasan Jati Diri Kemanusiaan}

Menurut Ghannoushi Islam tidak hanya mengakui hak hidup manusia beserta kebebasan dan keselamatannya, tetapi juga menganggap itu sebagai kewajiban suci bersama dan perorangan, berangkat dari prinsip bahwa manusia merupakan khalifah Allah di muka bumi yang dituntut untuk menegakkan keadilan bagi seluruh makhluk. Siapapun yang melakukan ketaatan kepada Allah dan menegakkan hukum secara adil di antara para makhluk, maka ia adalah khalifah Allah. $^{16}$

Pemuliaan manusia mencakup hak menjaga hidupnya dari gangguan dirinya sendiri atau dari pihak lain. Sebagaimana ditegaskan dalam firman Allah, "Dan janganlah kamu berbunuh-bunuhan sesama sendiri", 17 "Dan janganlah kamu membunuh jiwa yang diharamkan Allah [membunuhnya], melainkan dengan suatu [alasan] yang benar,". ${ }^{18}$ Ayat-ayat ini mengisyaratkan agar manusia menjaga dirinya dari apapun yang sekiranya dapat membayakan dirinya, seperti kemiskinan, kelaparan, penyakit, penggelandangan, penyiksaan, cemoohan, penghinaan, pengucilan, spionase, buruk sangka, gunjingan, fitnah, dan segala macam bentuk kezhaliman.

\footnotetext{
${ }^{15}$ Ibid hlm 48

${ }^{16}$ Rachid Ghannoushi, Al-Hurriyah al- 'Ammah fi al-Daulah al-Islamiyah, hlm 54

${ }^{17}$ al-Nisa`: 29

${ }^{18}$ al-Isra': 33
} 
Selain itu menurut Ghannoushi dengan sifat kemanusiaannya manusia memiliki kemuliaan/kehormatan tanpa melihat jenis, warna, keyakinannya, dan berbagai bentuk status atau pengakuan sosial. Kemuliaan itu berlaku baik saat ia masih hidup maupun saat ia mati. ${ }^{19}$ kebebasan merupakan nilai kemanusiaan yang sangat luhur, dan ia bisa kehilangan maknanya bila terlepas dari nilai-nilai kebenaran, kebaikan, keindahan, dan keadilan. Kebebasan tidak berlaku bagi orang zalim dan orang gila. ${ }^{20}$

\section{c) Kebebasan Berpikir dan Berekspresi}

Merupakan sesuatu yang wajar bila agama menempatkan manusia sebagai khalifah Allah Swt. karena potensi akal, kehendak, dan kebebasannya. Manusia tidak boleh membelenggu potensi-potensi tersebut, akan tetapi harus membebaskan dan mengembangkannya, serta melakukan ijtihad untuk mendorongnya agar selalu bergerak dan aktif. Dalam hal ini, peran agama cukup memberikan petunjuk dan arahan, serta membiarkan manusia menentukan sendiri perjalanan hidupnya dan menjaga tanggungjawab kekhilafahannya di muka bumi.

Menurut Ghannoushi kebebasan berpendapat mempunyai peranan besar dalam mengembangkan dan memajukan peradaban Islam. Lebih dari itu, kebebasan berpendapat juga memiliki kontribusi besar dalam mempersatukan umat Muslim dan menjauhkan mereka dari perang-perang antaragama dan antarsuku/ras seperti yang marak terjadi di dalam peradaban-peradaban lain akibat merebaknya fanatisme. Sejak awal, Islam sebenarnya sudah mengakui pluralitas agama, dan menjadikan ijtihad sebagai tugas mulia bagi setiap muslim sesuai dengan kadar keilmuannya. $^{21}$

\footnotetext{
${ }^{19}$ Rachid Ghannoushi, Al-Hurriyah al- 'Ammah fi al-Daulah al-Islamiyah, hlm 54

${ }^{20}$ Rachid Ghannoushi, Al-Hurriyah al- 'Ammah fi al-Daulah al-Islamiyah, hlm 56

${ }^{21}$ Rachid Ghannoushi, Al-Hurriyah al-'Ammah fi al-Daulah al-Islamiyah, hlm 56
} 


\section{d) Hak Asasi}

\section{Hak-hak dalam Bidang Sosial}

Menurut Ghannoushi yang dimaksud dengan hak-hak sosial adalah apapun yang dibutuhkan manusia untuk menunjang kehidupannya berupa mata pencaharian, sarana-sarana kesehatan dan sosialnya. ${ }^{22}$ Di antara hak yang dipandang sangat penting oleh Islam dan harus mendapatkan porsi perhatian yang cukup di dalam undang-undang kenegaraan adalah sebagai berikut:

\section{a. Hak-hak di Bidang Ekonomi}

Hak individu dalam kepemilikan termasuk di antara hak-hak dasar yang disebutkan secara tegas di dalam undang-undang negara tentang HAM dan dianggap sebagai hak alamiah. Sementara Islam menurut Ghannoushi, meskipun membolehkannya bagi setiap individu dengan beberapa syarat, hanya saja tidak menganggapnya sebagai hak alamiah, sebab kepemilikan seluruhnya hanyalah milik Allah Swt. Apapun yang berkaitan dengan kepemilikan, baik dalam proses pencariannya, pemanfaatkannya, dan jenis yang dimiliki, tidak sah kecuali sesuai dengan ketentuan yang telah digariskan syariat. Di dalam sejarah Islam, sampai masuknya imperialisme dan kolonialisme di abad ke-17, kepemilikan tidak dibangun di atas model kepemilikan seperti yang digagas oleh Karl Marx sebagai paradigma kepemilikan di dalam peradaban Eropa. Islam juga menganggap kepemilikan individual sebagai kepemikian absolut di mana si pemilik dapat memperjual-belikan, mewariskan, dan bahkan menghancurkannya, sebagaimana yang disebutkan di dalam dasar-dasar hukum Romawi. ${ }^{23}$

\footnotetext{
${ }^{22}$ Rachid Ghannoushi, Al-Hurriyah al- 'Ammah fi al-Daulah al-Islamiyah, hlm 60

${ }^{23}$ Ibid hlm 57
} 
Pernak-pernik kepemilikan yang dikenal di dalam negara-negara Islam berpijak di atas pembelanjaan (pemanfaatan) dan perwakilan; manusia mewaliki Tuhan di muka bumi dengan tanggung jawab memakmurkannya dan menjadikannya sebagai jembatan menuju akhirat. Kepemilikan pada manusia merupakan buah dari perannya sebagai wakil Allah. Artinya, bahwa pemilik yang sebenarnya adalah Allah Swt., dan bahwa kepemilikan pada manusia adalah 'kepemilikan perwakilan' atau 'kepemilikan pemanfaatan'. Manusia tidak bisa menggunakannya atau membelanjakannya kecuali sesuai dengan kehendak pemiliknya, yaitu Allah Swt. Kalau manusia menggunakannya secara menyimpang, maka hak kepemilikan itu akan hilang dengan sendirinya. Dan karena hak-hak serta kewajiban-kewajiban legal-positif memandang manusia sebagai makhluk sosial tersebab hidup di tengah-tengah lingkungan sosial tertentu, maka menjadi wajar bila proses kepemilikan dan pemanfaatan (pembelanjaan) itu dipandang sebagai bagian dari tugas-tugas sosial, ${ }^{24}$ guna menunjang bangunan masyarakat dan berfungsi untuk mengembangkan, memajukan, serta menjamin rasa aman di dalamnya. Namun, bila proses kepemilikan dan pemanfaatan itu dilakukan dengan cara-cara yang tidak baik, sudah pasti akan meruntuhkan keseimbangan sosial. Oleh karena itu, masyarakat mempunyai hak untuk merumuskan sendiri batasanbatasan dan ketentuan-ketentuan terkait proses kepemilikan dan pemanfaatan yang sejalan dengan tugas-tugas sosial-kemasyarakatan. ${ }^{25}$

Di antara tugas-tugas sosial-kemasyarakatan dalam konteks kepemilikan individual menurut Ghannoushi adalah: pembagian kekuasaan kepada setiap individu di dalam masyarakat secara merata melalui kepemilikan mereka terhadap bagian dari kekayaan, yakni sesuatu yang menjadi jaminan sosial bagi kebebasan politik dan musyawarah. Hal ini bertujuan agar kekayaan tidak hanya dikuasai oleh suatu kelompok tertentu, atau dikuasai oleh negara secara penuh sehingga

\footnotetext{
${ }^{24}$ Mustafa Kamal Washfi, al-Mulkîyyah fì al-Islâm, hlm. 73

${ }^{25}$ Rachid Ghannoushi, Al-Hurriyah al- 'Ammah fi al-Daulah al-Islamiyah, hlm 57
} 
melahirkan diktatorisme, dan agar di dalam masyarakat tidak ada dominasi 'orang yang punya' terhadap 'orang yang tidak punya'. Untuk itu, Islam mensyariatkan zakat sebagai jaminan sosial-kemasyarakatan dan dasar bagi kerjasama politik melalui musyawarah. ${ }^{26}$

Dari sana bisa dilihat perbedaan antara paradigma Islam dan paradigma Barat-Eropa, baik itu sosialisme yang melepaskan hak kepemilikan kekayaan dari setiap individu dan menguasakan sepenuhnya kepada negara, atau kapitalisme yang menguasakan kekayaan kepada sekelompok kecil orang. Sementara dalam paradigma Islam, kekayaan sebisa mungkin dibagi secara merata kepada setiap individu dalam masyarakat pada sebuah negara. Setiap orang menjadi pemilik, dan dengan begitu masing-masing ikut terlibat dalam kekuasaan dan pengambilan keputusan. Artinya, setiap individu mempunyai kebebasan dan hak untuk mengawasi kekuasaan serta menjaga keutuhan masyarakat secara menyeluruh dengan melakukan amar ma'rûf-nahî munkar sesuai dengan aturan-aturan yang telah ditetapkan bersama. ${ }^{27}$

\section{b. Hak Untuk Bekerja}

Di dalam salah satu karyanya, al-Dîmuqrâthîyyah fî al-Islâm ( Demokrasi dalam Islam ), Abbas Mahmud al-Aqqad menyimpulkan pendapat Ghannoushi tentang demokrasi Islam dalam satu kalimat, "Islam meniadakan hak investasi dan memuliakan hak untuk bekerja. Demokrasi tidak membutuhkan lebih dari dua kaidah ini untuk menjadi sangat mapan.,"28

Menurut Ghannoushi mestinya, negara berkewajiban menyediakan lapanganlapangan pekerjaan bagi siapapun dari warganya yang memiliki kemampuan.

${ }^{26}$ Ibid hlm 57

${ }^{27}$ Ibid hlm 57

${ }^{28}$ Abbas Mahmud al-Aqqad, al-Dîmuqrâthîyyah fî al-Islâm, Kairo: Dar el-Ma'arif, cet. I, 1971, hlm. 62 . 
Tugas negara bukan sebatas menjaga perbatasan dan membela kepentingan kelompok, tetapi yang paling penting dan paling mendasar adalah menegakkan keadilan. Negara memang harus menjamin kesejahteraan masyarakat; menyediakan makanan, tempat tinggal, pakaian, dan obat-obatan. Namun, yang lebih penting dan lebih utama dari itu adalah, sekali lagi, menyediakan lapangan-lapangan pekerjaan berikut fasilitas-fasilitas yang memadai. Seperti yang dilakukan oleh Nabi Saw. ketika beliau menganjurkan umat Muslim di zamannya untuk giat bekerja, dan menyediakan berbagai fasilitas untuk kepentingan itu bagi siapapun yang membutuhkan. Tidak hanya itu, beliau juga melakukan pengawasan terhadap aktivitas mereka sampai beliau benar-benar merasa yakin bahwa mereka bisa percaya diri dan berhasil dalam pekerjaan yang mereka upayakan. ${ }^{29}$

Zakat, yang disyariatkan oleh agama, bukan merupakan jaminan sosial terpenting di dalam negara Islam yang diberikan kepada orang-orang yang membutuhkan dan membuat mereka senantiasa mengulurkan tangan untuk mendapatkannya selama hidup. Zakat tidak diberikan kecuali pada saat-saat yang sangat mendesak. Mestinya, yang perlu diberikan kepada mereka, sesuai dengan keadaan dan kapasitas masing-masing, adalah lapangan-lapangan pekerjaan serta berbagai fasilitasnya (tempat kerja, pabrik-pabrik, tanah, atau modal usaha). Dalam hal ini, lembaga zakat bisa membantu mereka, lalu menasehati mereka agar bekerja secara mandiri dan seperti yang lain dapat bergerak aktif di pasaran, sampai akhirnya mereka menjadi pemberi zakat, bukan penerima zakat. ${ }^{30}$

\section{c. Hak Layanan Kesehatan}

Hak sosial lain yang perlu mendapatkan perhatian dari negara bagi warganya menurut Ghannoushi adalah layanan kesehatan. Nabi Muhammad Saw., seperti

\footnotetext{
${ }^{29}$ Rachid Ghannoushi, Al-Hurriyah al- 'Ammah fi al-Daulah al-Islamiyah, hlm 62

${ }^{30} \mathrm{Ibid}$
} 
diketahui sangat memperhatikan apa yang saat ini disebut 'kedokteran preventif' berupa kebersihan dan keseimbangan hidup, yaitu dengan menjaga diri dari berbagai macam najis atau kotoran, hal-hal yang memabukkan, serta berbagai bentuk pemborosan dan kerusakan.

Beliau sangat menganjurkan aktivitas olah raga, mewajibkan siapapun dari umatnya yang sakit untuk segera berobat, serta melarang mereka untuk menjadi kegemukan akibat banyak makan dan rakus. ${ }^{31}$ Bahkan, karena alasan kesehatan, beliau banyak memberikan keringanan dalam hal pelaksanaan ibadah. Beliau juga mewajibkan negara menyediakan layanan pengobatan kepada siapapun dari warganya yang membutuhkan, baik muslim maupun non-muslim. Tidak heran bila peradaban Islam di masa lalu banyak membangun sarana-sarana kesehatan terbaik, seperti rumah sakit, apotek, dan laboratorium. ${ }^{32}$

\section{d. Hak Membangun Keluarga}

Salah satu hak sosial yang ditekankan oleh Islam adalah hak membangun keluarga. Bagaimanapun, perkawinan adalah bagian dari hukum alam. Selain itu, bagi orang-orang mukmin, perkawinan termasuk ibadah yang setara separuh agama ditinjau dari sisi pengaruh berupa keseimbangan kepribadian dan perkembangannya, serta merupakan bingkai tak tergantikan untuk menjaga keberlangsungan kehidupan manusia dan pertumbuhannya. Untuk itu, Islam sangat memperhatikan institusi perkawinan dengan menentukan hak-hak dan kewajibankewajiban masing-masing pihak, laki-laki dan perempuan, atas dasar equalitas dan integralitas. $^{33}$

\footnotetext{
${ }^{31}$ Ibid hlm 64

${ }^{32}$ Ibid

${ }^{33}$ Ibid hlm 65
} 
Perkawinan merupakan perjanjian yang mulia, komitmen yang kokoh, dan institusi agung dengan ikatan-ikatan sangat rumit dan berkelindan. Islam membangunnya berdasarkan kerelaan, saling menghormati, dan spirit kemanusiaan mendalam, seperti keimanan, keihsanan, kesabaran, cinta-kasih sayang, dan keadilan. Melalui perkawinan ini Islam sebenarnya bertujuan menghilangkan sekatsekat rasialisme yang menjadi penghalang utama bagi manusia untuk menjalin hubungan kerjasama (saling tolong-menolong), kerukunan, dan kekerabatan. ${ }^{34}$

\section{e. Hak untuk Belajar dan Mendapatkan Pendidikan}

Menurut Ghannoushi peradaban Islam datang untuk mengejawantahkan prinsip "ilmu adalah wajib" di dalam realitas. Sebagian penulis sejarah peradaban melihat bahwa Cordoba, misalnya, merupakan kota pertama dalam Islam yang berhasil menghapuskan buta huruf. ${ }^{35}$ Keberhasilan itu tidak menjadi beban bagi keseimbangan negara, dan kebudayaan Islam yang mengaitkan antara ilmu dengan iman, dunia dan akhirat, berdasarkan prinsip bahwa manusia merupakan khalifah, bertanggungjawab mendirikan lembaga-lembaga keilmuan masyarakat dan mendanainya dari badan-badan wakaf negara. ${ }^{36}$

Meskipun begitu, lembaga-lembaga pendidikan dan pengajaran berdiri secara independen terlepas dari campur-tangan negara dan dipandang sebagai bagian dari struktur masyarakat madani dilihat dari sisi bahwa pendidikan dalam Islam tidak hanya diperuntukkan bagi anak-anak di usia dini, tetapi juga untuk masyarakat secara keseluruhan tanpa terkecuali, dan bahwa pengajaran paling mendasar tidak hanya terbatas pada tiga keahlian: membaca, menulis, dan menghitung, tetapi juga mencakup bidang nilai-nilai dan pengembangannya. Karena, apapun alasannya, ilmu sama sekali tidak akan bermakna tanpa disertai dengan amal saleh (perbuatan

\footnotetext{
${ }^{34}$ Ibid

${ }^{35}$ Segraid Hunkat, Syams al-'Arab Tastha' 'alâ al-Gharb, Rabithah al-Alam al-Islami, cet. VIII, 1972.

${ }^{36}$ Rachid Ghannoushi, Al-Hurriyah al- 'Ammah fi al-Daulah al-Islamiyah, hlm 66
} 
baik) untuk menunjang kemajuan individu dan komunitas masyarakat, juga untuk meraih kebahagiaan dunia-akhirat melalui pemanfaatan dan pengembangan potensi-potensi material dan spiritual, baik pada anak-anak kecil maupun orangorang dewasa, laki-laki maupun perempuan, selaras dengan manhaj ilahi untuk menggapai kemenangan dengan ridha-Nya. ${ }^{37}$

\section{f. Hak Jaminan Sosial}

Islam merupakan agama pertama yang menggariskan jaminan sosialnya mencakup orang-orang berhutang sampai hutang-hutang mereka terlunasi dan terlepas dari kesulitan; para budak sampai mereka dimerdekakan; para gelandangan dan pengangguran; para musafir, dari negeri yang sangat jauh, meskipun mereka memiliki kekayaan yang banyak di negerinya.

Jaminan sosial Islam juga mencakup anak-anak kecil yang tidak mempunyai wali sampai mereka menemukan wali yang mau mengasuh dan membesarkan mereka, juga mencakup fasilitasi perkawinan bagi siapapun yang tidak mempunyai wali atau tidak mempunyai harta. Para sejarawan menyebutkan, bahwa di masa kekhalifahannya, Sayyidina Umar ibn al-Khatthab membangun sebuah gedung yang di dalamnya tersedia berbagai kebutuhan hidup sehari-hari seperti sagu, tepung, kurma, minyak, dan lain sebagainya yang dikhususkan bagi mereka yang membutuhkan. Dari sini bisa dilihat keunggulan jaminan sosial yang dikembangkan dan dipraktikkan di dalam Islam. Dan itu berdasarkan perspektif hubungan individu, masyarakat, dan negara. ${ }^{38}$

\section{g. Hak dalam Keadilan Hukum}

${ }^{37}$ Abu Abdillah Muhammad ibn Abi Bakr ibn Qayyim al-Jauziyah, Tuhfat al-Mawlûd bi Ahkâm al-Mawlûd, Bombai: al-Jami'ah al-Hindiyah al-Arabiyah, cet. I, 1961

${ }^{38}$ Rachid Ghannoushi, Al-Hurriyah al-'Ammah fi al-Daulah al-Islamiyah, hlm 71 
Menurut Ghannoushi keadilan merupakan nilai mutlak yang tidak dapat dibatasi oleh apapun, baik agama, kepentingan, atau yang lainnya. Banyak sekali teks agama yang menegaskan hal itu dan mendorong umat Muslim untuk melakukan revolusi besar guna menghasilkan undang-undang keadilan dalam kaitannya dengan interaksi sosial, di samping juga membuat peraturan pengadilan dengan menetapkan syarat-syarat yang ketat bagi para hakim; mereka harus berilmu luas, berakhlak mulia, tulus, bersih, suci, berani, dan tegas. Dengan begitu, mereka dapat menempati kedudukan yang tinggi di mata masyarakat, juga akan mampu bersikap independen sehingga tidak ada seorang pun, bahkan penguasa sekalipun, yang dapat mempengaruhi dan mengintervensi keputusan hukum yang mereka ambil. Contoh yang paling layak untuk dilihat adalah praktik-praktik pengadilan di masa Nabi Saw. dan al-Khulafầ al-Râsyidûn. ${ }^{39}$

\section{h. Hak Keamanan atau Suaka Politik}

Menurut Ghannoushi di dalam atmosfir keamanan dan keadilan yang dijamin oleh masyarakat Muslim bagi mereka yang non-muslim dari berbagai suku dan aliran, tercipta ruang-ruang dialog dan penelaahan langsung terhadap hakikat ajaran Islam. Demikianlah, Islam menjadi agama pertama yang secara teori dan praktik mengakui apa yang saat ini dikenal dengan "suaka politik" yang juga ditegaskan oleh PBB. Namun yang paling aneh, dulu, di masa keemasan peradaban Islam, masyarakat-masyarakat Muslim di negara-negara mereka sendiri dapat bergaul dengan tokoh-tokoh intelektual dari luar, juga dengan kaum minoritas dari berbagai agama. Tetapi di zaman sekarang, tokoh-tokoh pemikir, kelompok-kelompok politik, di antaranya adalah kelompok-kelompok Islam sendiri, karena alasan keamanan, sosial, dan politik, justru keluar dari negeri-negeri Muslim untuk meminta suaka politik dari negeri-negeri luar, khususnya negeri-negeri Eropa dan

\footnotetext{
${ }^{39}$ Rachid Ghannoushi, Al-Hurriyah al- 'Ammah fi al-Daulah al-Islamiyah, hlm 73
} 
Barat. Hal ini menunjukkan bahwa nilai-nilai khas peradaban Islam di masa lalu seperti kebebasan, keamanan, kreativitas, progresivitas, persamaan, kesetaraan, toleransi, dan keadilan, sekarang sudah memudar. Jelas, ini merupakan sebuah kemunduran. $^{40}$

\section{Kesimpulan}

Ghannoushi adalah sosok yang mempu memberi pengaruh dalam perkembangan dan dinamika politik di Tunisia. Ia merupakan cerminan rakyat Tunis yang merindukan adanya kebebasan dan terangkatnya hak-hak asasi kemanusian yang terpasung sejak kemerdekaan diraih pada tahun 1957. Diawal perjalanannya, Ghannoushi telah melihat dan merasakan ketimpangan kebijakan yang dibangun oleh penguasa negeri itu selama dua generasi kepemimpinan, dimulai dari kepemimpinan Presiden Bourguiba yang dikenal sebagai Presiden sekuler serta kepemimpinan Presiden Zein el-Abidini Ben Ali yang dikenal sebagai Presiden diktator dan berkuasa selama 23 tahun.

Dari masa kepemimpinan dua generasi Presiden tersebut, Ghannoushi belum merasakan adanya jaminan kebebasan dan hak asasi manusia bagi rakyat Tunisia. Justru yang ia rasakan adalah ketimpangan sosial dan politik serta hegemoni kediktatoran pemimpin negeri tersebut. Gannoushi selanjutnya melakukan ekspansi pemikiran dengan cara belajar ke berbagai tokoh di beberapa negara untuk menggali dan menemukan sistem ketatanegaraan yang cocok bagi perkembangan Tunisia. Hingga ia menjadikan nilai-nilai demokrasi sebagai sistem yang menurutnya relevan untuk memajukan kesejahteraan rakyat Tunisia.

Nilai-nilai demokrasi tersebut selanjutnya diaplikasikan dalam sebuah organisasi nasional bernama Islamic Association pada tahun 1979. Namun, ketika

\footnotetext{
${ }^{40}$ Rachid Ghannoushi, Al-Hurriyah al- 'Ammah fi al-Daulah al-Islamiyah, hlm 74
} 
Presiden Bourguiba memberi kelonggaran pada sistem politik satu partai di Tunisia, organisasi Islamic Association ditransformasikan menjadi partai politik bernama the Islamic Tendency Movement (MTI), walaupun Bourguiba sendiri menolak memberi ijin bagi berdirinya partai tersebut. Hingga pada lintasan sejarah MTI kembali akhirnya dibubarkan secara paksa pada tahun yang sama dan memenjarakan para petingginya, termasuk Ghannoushi.

Cita-cita besar Ghannoushi untuk membangun kebebasan dan jaminan hak asasi manusia tetap tidak surut. Terbukti ia kemudian mendirikan Partai an-Nahdah pada tahun 1988 dengan memanfaatkan kelonggaran politik yang diberikan oleh Ben Ali sebagai Presiden yang menggantikan Bourguiba. Namun, perjuangan Ghannoushi dalam pentas politik t 114 baru dapat direalisasikan pasca revolusi Tunisia tahun 2011. Pada saat itulah ia bersama dengan rakyat Tunisia mampu menerapkan nilai-nilai dasar demokrasi berupa kebebasan dan jaminan hak asasi manusia yang dituangkan dalam konstitusi baru Tunisia. 


\section{DAFTAR PUSTAKA}

Ahmed. O. Altwajri, Islam Barat dan Kebebasan Akademis, Penerjemah Mujib, ed., Musyafak Maimun, (Yogyakarta: Titian Ilahi, 1997), Cet I

Ahmad Daudy, Kuliah Filsafat Islam, (Jakarta: Bulan Bintang, 1986)

Aisyiah Binti Syati, Manusia dalam Perspektif Al-Qur'an, Alih Bahasa Ali Zawawi, (Jakarta: Pustaka Firdaus, 1999)

Abbas Mahmud al-Aqqad, al-Dîmuqrâthîyyah fì al-Islâm, (Kairo: Dar el-Ma'arif, cet. I, 1971)

Abu Ja'far Muhammad ibn Jarir al-Thabari, Tafsîr al-Thabarîy, Jâmi' al-Bayân 'an Ta 'wîl Âyi al-Qurân, terj. Muhammad Syakir, (Kairo: Dar el-Ma'arif)

Abdul Ghany Bin Muhammad bin Ibrahim Ar-Rahhal, Al-Islamiyun wa SarabudDimuqrathiyah, terjemahan Kathur Suhardi, (Bandung: DeA Press, 1999).

Bin Muhammad Ar-Rahhal ,FenomenaDemokrasi

StudiAnalisisPerpolitikanDunia Islam ( Jakarta : Dea Press, 2000 )

Abdulkarim, Pendidikan Kewarganegaraan: Membangun Warga Negara yang Demokratis, (Jakarta: PT Grafindo Media Pratama, 1999)

Budi Munawar, Rahman, Kontekstualisasi Doktrin Islam dalam Sejarah, (Jakarta: Paramadina, 1995)

Dede Rosyada Dkk, Pendidikan Kewarganegaraan :Demokrasi, Hak Asasi Manusia dan Masyarakat Madani ( Jakarta : Kencana, 2003 )

Departemen Kebudayaan dan pendidikan, Kamus Besar Bahasa Indonesia, ( Jakart : Balai Pustaka, 1993)

David Little, John Kelsey dan Abdul Aziz Sachedina, Kajian Lintas Kultural Islam

Barat: Kebebasan Agama dan Hak-Hak Azasi Manusia, (Yogyakarta: Pustaka Pelajar, 1997)

Dustur al-Jumhuriyah at-Tunisiyah, Pasal 1 hlm. 3.

Edward Montimer ,Islam dan Kekuasaan ( Bandung : Mizan , 1984 ) 
FazlurRahman, Islam, ( Bandung : Pustaka, 1984 )

John O. Voll, "Sultans, Saints and Presidents: The Islamic Community and theState in North Africa ”, dalam John P. Entelis, (ed.), Islam, Democracy, and the State in North Africa,(Indiana: Indiana University Press, 1997)

JohnL. Esposito, Islamand Democracy, terj. Rahmani Astuti dengan judul Demokratisasi di Negara-negara Muslim:Problem dan Praktek.(Bandung :Mizan, 1999) andJhon O. Voll, Tokoh Kunci Gerakan Islam Kontemporer, terj.

Sugeng Hariantodkk, cet. ke-1(Jakarta: PT. Raja GrafindoPersada, 2002) 1996)

Khaled Abou el-Fadl, Islam dan Tantangan Demokrasi, terj. Gifta Ayu Rahmani dan Ruslani, (Jakarta: Ufuk Press, 2004)

Katsir Ibn, Tafsîr al-Qur 'ân al- 'Azhîm, Jilid 4

Mustafa Kamal Washfi, al-Mulkîyyahfí al-Islâm

Moh.Kusnardi, PengantarHukum Tata Negaara Indonesia, PusatStudiHukun Tata Negara, (Jakarta: CV Seminar Bakti, 1976)

Muhdin Zuhri, Transformasi Agama Dalam Pergerakan HAM Era Transisi, (Jakarta: CV,Citra Total Estetik, 2002)

Mun'im A. Sirry, Dilema Islam Dilema Demokrasi, (Bekasi: PT. Gugus Press, 2002)

Miriam Budiardjo, Demokrasi di Indonesia, Demokrasi Parlementer dan Demokrasi Pancasila, (Jakarta: PT Gramedia Pustaka Utama, 1976)

Majdi Abdul Mu'thi, RachidGannoushi: al-Nahdhah al-Islamiyah fi Tunis, (Mesir: al-Dar al-Dzahabiyah, 2012)

Muhammad Imarah, Islam dan Keamanan Sosial, (Jakarta :GemaInsani Press 1999)

Muhammad Ngajenan, Drs, Kamus Etimologi Bahasa Indonesia, Dahara Prize, Yogyakarta, 1986 
M. IqbalHasan, Pokok-pokok Materi Metodologi Penelitian Dan Aplikasinya,(Jakarta: Ghalia Indonesia, 2002 )

NicoSyukurDister OFM, Dr,FilsafatKebebasan, (Yogyakarta, Kanisius 1998)

Nurdiaman, Pendidikan Kewarganegaraan: Kecakapan Berbangsa dan Bernegara, (Jakarta: PT Grafindo Media Pratama, 1999)

MaskyuriAbdillah, Demokrasi di PersimpanganMakna :ResponIntelektual MuslimIndonesia Terhadap Konsep Demokrasi, (Yogyakarta: Tiarawacana, 1999)

Machasin, Menyelami Kebebasan Manusia, (Yogyakarta: Pustaka Pelajar, 1996)

M. Hasyim Kamali, Kebebasan Berpendapat dalam Islam, Alih Bahasa Efa. Y.Nu'mandan Fatiyah Basri, (Bandung: Mizan, 1996), hlm 225

Madjid Khudari, Teologi Keadilan Perspektif Islam, (Surabaya: Risalah Gusti, 1999)

RachidGannoushi, al-Harakah al-Islamiyah fi Tunis, (Tunis: Dar al-Mujtahid, 2011)

Min Tajribah al-Harkah al-Islamiyah fi Tunis, ( Tunis : Dar alMujtahid, 2011 )

Syekh Syaukat Hussain, Hak Asasi Manusia dalam Islam ( Jakarta : GemaInsani Press, 1996)

Sukron Kamil, Islam dan Demokrasi: Telaah Konseptual dan Historis. (Jakarta: Gaya MediaPratama,2002)

\section{Journal}


ArezkiDaoud, "Opposition Parties in Tunisia at the Eve of the Elections." North Africa Journal,no. 66, September 30, 1999. At http://www.northafrica.com/archives/docs/093099A.htm

Bayat, Asef, Islam and Democracy: What is the Real Question? Amsterdam: Amsterdam University Press, 2010.

NurcholisMadjid, Islam danPolitik: SuatuTinjauanAtasPrinsipprinsipHukumdankeadilan, JurnalPemikiran Islam Paramadina, Vol 1 No 1, (Jakarta : Paramadina, 1998)

Stephen J. King, Liberalization against Democracy"

Rachid Gannoushi, "Secularism in the Arab Maghreb," dalam Islam and Secularisme in the Middle East, (New York: New York University Press, 1999)

\section{Media}

Mohamad Guntur Romli dalam www.internasional.kompas.com "Islam Politik di Tunisia".

Radwan Masmoudi dalam artikelnya yang berjudul Islam dan Demokrasi Tidak Bertentangan di Tunisia, lihat www.commongroundnews.org 